\title{
Graduates of Private Schools and the Greek University: Empirical data and sociological interpretations through the period of crisis
}

\author{
Nikos Fotopoulos \\ Department of Social and Education Policy, \\ University of Peloponnese. \\ Christos Zagkos \\ Department of Philosophy, \\ University of Ioannina. \\ Polina Fatourou \\ Statistical Researcher, \\ Center of Educational Policy Development (KANEP/GSEE).
}

\begin{abstract}
In modern Greece, the entrance in higher education is considered a kind of social 'fetish'. In this concept, the Greek family diachronically strives to provide its members with an academic perspective, even if this parental choice is linked to many economic and psychological sacrifices. Private education is often associated with the perspective of a better academic and career prospect which is necessarily linked to entrance procedures at the Greek university. During the period (2001-2011) the representation of private school graduates in the total student population seems to be under "representative normality". Additionally, private school students appear to have the same overall possibilities (neither less nor more) with public school graduates into higher education. However, a deeper sociological analysis demonstrates significant differences in the representation of higher education between public and private schools. This report focuses on private school graduates and more generally on the interpretation of how their entrance into higher education is portrayed.
\end{abstract}

Key words: education, privatization, stratification, social and educational inequalities, higher education

\section{INTRODUCTION}

The challenge of tertiary education and the entrance to academic life constitutes one of the most significant goals for every student in Greece for many decades. This social attitude towards academic studies is linked to the general passion for social, and the educational mobility through the dominant stratification due to education apparatuses has been the most reliable instrument for personal, professional and social prosperity (Sianou-Kyrgiou, 2010). Additionally, the social vision for a better life has become synonymous with the passion for better education and training, especially for those who are socially originated by low and mid classes (Sianou-Kyrgiou, 2008). Paradoxically in Greece, decades ago, a fixed trend of privatization through the educational system which is based on a private lesson, private tutorial, and studies in private institutions, has been formed (Kassotakis, \& Verdis, 2013). According to this trend, parental choices are determined drastically by the dominant stereotypes which theorize private education as a superior field in contrast to the public institutions. Generally, this attitude leads $6-7 \%$ of students' population to private schools 
seeking a more qualified academic and cultural environment extremely different from the conventional normality of public schools.

In this paper we will examine:

- How the graduates of private schools participate in Greek universities?

- What are the basic trends towards Greek Universities?

- Which are the most sought-after fields of study?

- How graduates of private schools are represented through both the field of studies and prestigious types of education?

- In what way educational outcomes from private schools are affected by the period of crises?

- What is the role of private schools in the process of educational and social mobility?

It is very important to refer that, after taking into consideration our research assumption, the role of private schools seems to be extremely drastic to the students' orientation towards universities. Following, analyzing and interpreting the empirical data for the period 2001-2011 in contemporary Greece we can shed light upon facets, dimensions, and trends by providing a stable and constructive approach stemming from concepts and instruments of sociological discipline. Undoubtedly, we will provide useful research outcomes by taking advantage of the empirical and statistical data during the last decade as provided by the Center for Educational Policy Development (KANEP/GSEE).

\section{THEORETICAL AND CONCEPTUAL FRAMEWORK}

Before referring anything about the role of private education, it is essential to broach the issue of historical and social features that have shaped the peculiar framework of education in modern Greece. Since the establishment of the modern Greek state after the Second World War, education emerged as the main reliable and competitive apparatus for professional and social upward mobility. (Zambeta, 2014). Since the 1950s and 1960s, every family in Greece shapes its strategy by promoting the entrance in the Greek University as an utmost priority. Gradually, the Greek state regulated the public process for access to tertiary education establishing a widely accepted and well-known institution called national examinations (Panhellenic exams) to provide equal and transparent opportunities to all. Undoubtedly, the Greek family has to spend a huge amount of its annual budget for the preparation of pupils through this specific and competitive process (Sianou-Kyrgiou, 2008). It is estimated that the private expenditure for private lessons and private educational goods and services in Greece is at the same high level as the public one. This directly verifies the significant role of education through the Greek culture regardless of social origin or stratification (Kassotakis, \& Verdis, 2013). Consequently, through this "mass trend" for better and more effective education, many Greek families prefer investing in private schools theorizing them as more reliable and culturally inclusive institutions (Therianos, \& Fotopoulos, 2011). Even if it is difficult to analyze holistically the role of private education, we will argue that there is (obviously biased) an extensively accepted collective representation that private schools provide many comparative advantages in contrast to public schools: educational activities, cultural projects, additional learning, safe and oriented environment, counseling and professional orientations, wider social networks e.t.c (Therianos, \& Fotopoulos, 2011). Undoubtedly, all of these "facilities" strengthen the role and dynamism of private schools especially for high-class families who are capable of affording expensive fees. On the other side of the coin, less privileged families strive hard to follow the main tendency without having other alternative parental choices for their pupils. 
Fatefully the entrance in University for the vast majority of the population remains the main pathway for upward mobility despite the visible risk of high unemployment or an inability for a better job. Specifically, after 2008, the so-called "memorandum era", Greek society suffered from hard measures of public austerity. Unfortunately, the tough period of fiscal consolidation provoked extremely negative consequences to the field of public education (Zambeta, 2014). Paradoxically, the field of private education and especially the total expenditure for private schools remained relatively fixed depicting that social trust to private schools had been stronger than ever.

Hence, we have to examine deeply the operation of private schools through the function of national examinations for entrance to universities. According to many pieces of research, a straight correlation between private schools and the degree of success of their graduates is consolidated. It is more than certain that the educational provisions and infrastructures of private schools affect positively their students' learning outcomes even though exams are extremely competitive and demanding. Additionally, students from private schools enjoy more opportunities to follow subsidiary education in a parallel way, thus supporting their preparation for the Panhellenic exams. Apart from this "privileged strategy", they have more means to utilize practical and instrumental facilities to prepare themselves for this tough and psychologically exhausting procedure.

It is doubtless that they have deeply internalized the core of this process, thus building their educational path with rationalism and no regressions. In this strategy, a significant role plays not only the effort of individuals but the well-structured "cultural capital" which their families have gradually developed. According to the new sociology of education, the role of cultural capital is being proved extremely decisive for shaping not only the educational mobility but also the future career pathways (Giroux, 1983). This means that apart from the instrumental and other "technical issues" concerning the preparation for the state exams, students of private schools seem to appear more prepared and effective for this choice. With no doubt they feel more closely to prestigious fields of studies, they internalize in a more "natural mood" the whole process, as well as they, are more conformed to the sovereign rules and values. According to many theorists, this "physical" feeling is based on their social origin and their certainty that are the "legal heirs" of knowledge and social power (Whitty, Power, \&Halpin,1998, Ball, \& Vincent, 2011). We can understand that parental choice concerning the private schools is based not only on practical and educational reasons but also on cultural and prestigious motives which strengthen their institutional legitimacy through the system of social stratification (Gouvias,1998).

Apart from the "hegemonic role" of private schools in the collective representations, it is very important to mention that, according to our empirical data, graduates from private schools are over-represented in the Greek university. Both prestigious and highly demanding academic faculties and departments attract students from private schools, a result which is grounded on the recycling of elites through the educational ranking (Gouvias, 1998). Inevitably, this maintains and reproduces the dominant educational and social inequalities, and, at the same time, preserves the pathogeny of the sovereign status quo (Gouvias, 1998). Unfortunately, this vicious cycle of inequality has become wider and more visible during the period of crisis when middle classes absorbed the hardest and most difficult part of austerity measures.

Concluding this short theoretical approach, we will present all the key findings from 20012011 to reflect the map of representation of graduates from private schools to the Greek universities. It is explicit that we will highlight only basic facets and dimensions of this trend and in no case the whole view of the Greek educational reality. At the same time, this reference 
includes a great opportunity to show off and rethink the relationship between the "private and public" sphere, especially in an era that is rapidly and drastically evolving. Arguably, the research and sociological rethinking should be placed at the epicenter of our civic interest promoting all means for growth and social justice.

\section{DATA}

The data used in this paper are derived from the Survey "Statistical Personal Student File" conducted for Tertiary Education by Hellenic Statistical Authority, which collects census data ${ }^{1}$ on all undergraduate students who are enrolled for the first time at the beginning of each academic year per department of Greece's Tertiary education ${ }^{2}$. Moreover, census data on the graduates from upper secondary education in Greece collected by Hellenic Statistical Authority were used, in order to compare the share of private school graduates with the share of new entrants in tertiary education holding an upper secondary school certificate from a private school, and thus to calculate the odds ratio for participating in tertiary education for private school graduates. All data for this study have been provided to the authors by the Centre of Educational Policy Development (KANEP) of GSEE (Greek General Confederation of Labour).

An aggregated indicator has been calculated for each department to report the share of new entrants in tertiary education holding an upper secondary school certificate from a private school. In order to study the real change over time of this figure, it has been calculated also the share of private upper secondary school graduates in total graduates from this level per year.

The probability ratio for participating in tertiary education is calculated by dividing the share of new entrants in tertiary education holding an upper secondary school certificate from a private school by the share of private upper secondary school graduates in total graduates from this level for each year. A probability ratio value $<1.0$ in department $\mathrm{x}$ indicates that private school graduates are less likely to enter in department $\mathrm{x}$ than their peers from public schools. In other words, a value $<1.0$ indicates that private school graduates are underrepresented in department $\mathrm{x}$. On the other hand, a probability ratio value $>1.0$ in department $\mathrm{x}$ indicates that private school graduates are more likely to enter in department $\mathrm{x}$ than their peers from public schools, or else that private school graduates are overrepresented in department x. A probability ratio of 1.0 represents equal chances of participating in tertiary education between private and public school graduates.

${ }^{1}$ Data on Military Academies, Police Academies, Fire Academies, Hellenic Open University and International Hellenic University are not published by EL.STAT., thus they are excluded from the analysis.

2 "Tertiary education consists of two main parallel sectors:

- Universities, including all the universities, Polytechnic Schools and the Athens School of Fine Arts and

- Technical Sector which encompasses the Technological Educational Institutes (TEI) and the Higher School of Pedagogic and Technical Education (ASPAITE). The survey on the technical sector also covers the Higher Ecclesiastical Academies, the Merchant Marine Academies (AEN), as well as the Higher Schools for Services and the Artistic Schools."

(EL.STAT., (2014) Survey on Tertiary Education (Universities - Technical Sector) - Personal Statistical Student File, Single Integrated Metadata Structure, https://www.statistics.gr) 


\section{FINDINGS}

Table 1. Population rate holding at least a University degree in 2018 (age:25-34, ISCED:5-8)

\begin{tabular}{|c|c|c|c|c|c|}
\hline & E.U. 28 & 40,0 & & & \\
\hline 1 & Cyprus & 58,5 & 15 & Latvia & 41.6 \\
\hline 2 & Ireland & 56,2 & 16 & Slovenia & 40.7 \\
\hline 3 & Lithuania & 55,6 & 17 & Austria & 40.5 \\
\hline 4 & Luxembourg & 53,7 & 18 & Finland & 40.3 \\
\hline 5 & $\begin{array}{l}\text { United } \\
\text { Kingdom }\end{array}$ & 48,1 & 19 & Malta & 40.0 \\
\hline 6 & Sweden & 47,6 & 20 & Slovakia & 37.2 \\
\hline 7 & Netherlands & 47,6 & 21 & Croatia & 35.4 \\
\hline 8 & Belgium & 47,4 & 22 & Portugal & 35.1 \\
\hline 9 & France & 46,9 & 23 & Bulgaria & 34.0 \\
\hline 10 & Denmark & 46,8 & 24 & Czechia & 33.3 \\
\hline 11 & Spain & 44,3 & 25 & Turkey & 32.1 \\
\hline 12 & Estonia & 43,7 & 26 & Hungary & 30.6 \\
\hline 13 & Poland & 43,5 & 27 & Italy & 27.7 \\
\hline 14 & Greece & 42,8 & 28 & Romania & 24.9 \\
\hline
\end{tabular}

Source: Eurostat. Population by educational attainment level, sex, and age (\%) - main indicators [edat_lfse_03]

According to Table 1, Greece has a fairly high rate of tertiary education graduates between the ages of 25 and 34 and is in the middle of the list (14th), reaching $42.8 \%$ in 2018 slightly higher than both the European average and the European target for 2020, which is $40 \%$ of the population of this population to have at least a higher education degree. This, on the one hand, confirms the prevailing view that access to higher education is a priority for the Greek family, but does not confirm the neo-liberal rhetoric that refers to a 'surplus' of graduates and' massproduction ' of diplomas without any connection to the labor market.

Figure 1. Graduates rate of tertiary education level (Bachelor's or equivalent- ISCED 6) by field of education in Greece (2017)

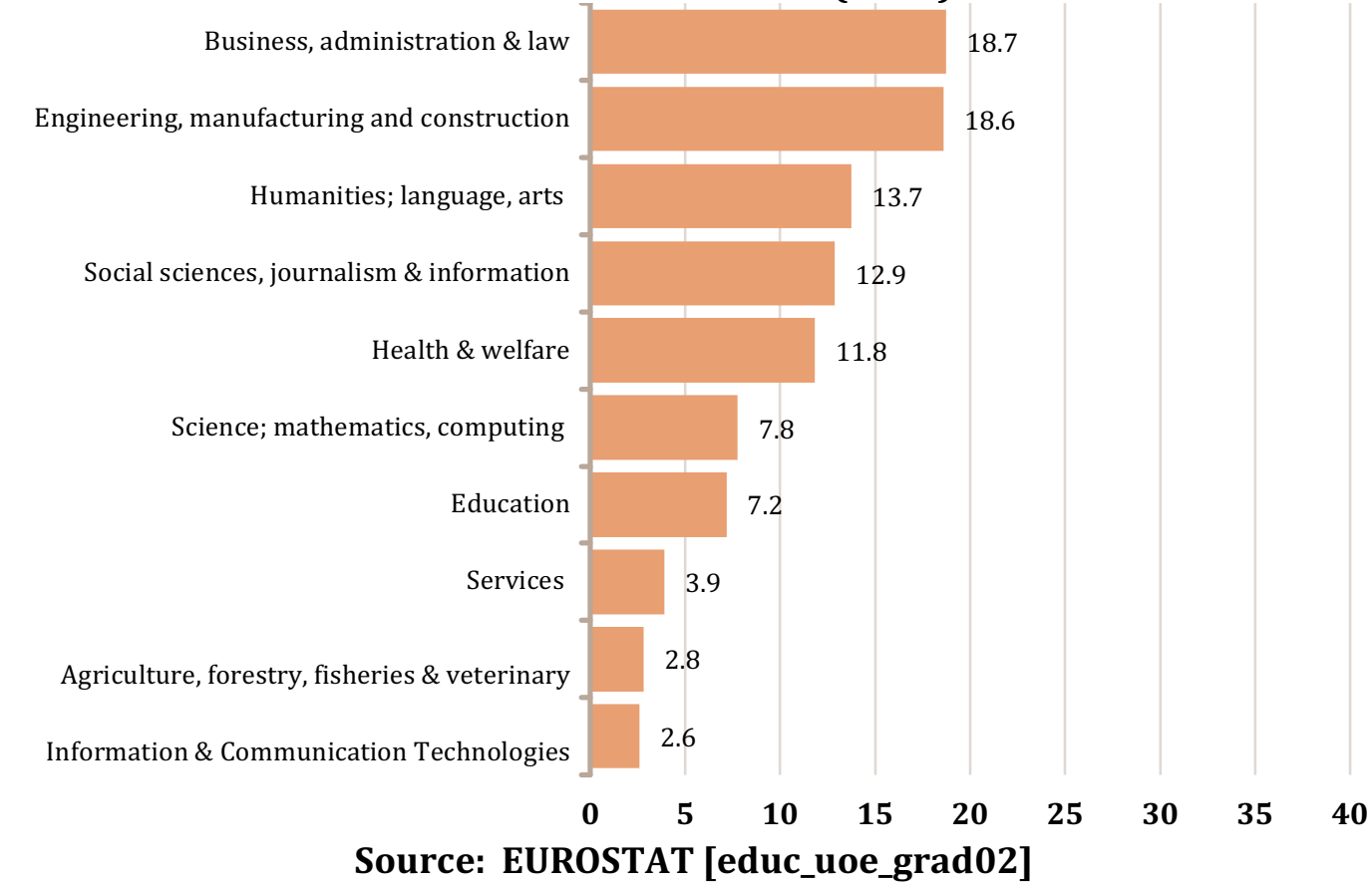


Regarding the subject of study chosen by the Greek students, according to the above graph, we can see that $18.7 \%$ of the graduates of higher education have Bachelor of Law, Administration, and Business, with a similar percentage $(18.6 \%)$ to choose engineering, manufacturing and construction studies. Subsequently, $13.7 \%$ of the graduates are graduates of fine arts, humanities and language studies, while $12.9 \%$ are graduates of social studies and journalism. However, it is striking that only $2.6 \%$ of higher education graduates are graduates of ICT departments.

Concerning the private education in Greece, in 2014, out of a total of 1,433,308 students studying in Primary \& Secondary Education, 94.6\% (or 1,355,990 students) study in public schools while $5.4 \%$ (or 77318 students) attend private education. The student population in the private sector of Primary \& Secondary Education in Greece enrolls a strong decline of 16,024 students (or $-17.2 \%$ ) from 93,342 students in 2002 at 77,318 students in 2014.

Table 2. Secondary general education (upper secondary schools): School units, teaching staff and pupils, end of the school years 2000/01 - 2012/13

\begin{tabular}{|c|c|c|c|c|c|c|c|c|c|c|}
\hline & \multicolumn{5}{|c|}{ Total (Public \& Private) } & \multicolumn{5}{|c|}{ Private Schools } \\
\hline & $\begin{array}{c}\text { School } \\
\text { units }\end{array}$ & $\begin{array}{c}\text { Teaching } \\
\text { staff }\end{array}$ & Pupils & enrolled $^{3}$ & graduated & $\begin{array}{c}\text { School } \\
\text { units }\end{array}$ & $\begin{array}{c}\text { Teaching } \\
\text { staff }\end{array}$ & Pupils & enrolled & graduated \\
\hline $2000 / 01$ & 1,289 & 25,381 & 241,214 & 80,574 & 72,023 & 1,289 & 25,381 & 241,214 & 80,574 & 72,023 \\
\hline $2001 / 02$ & 1,238 & 25,409 & 230,165 & 75,019 & 73,022 & 1,238 & 25,409 & 230,165 & 75,019 & 73,022 \\
\hline $2002 / 03$ & 1,268 & 25,598 & 228,747 & 78,141 & 72,412 & 1,268 & 25,598 & 228,747 & 78,141 & 72,412 \\
\hline $2003 / 04$ & 1,290 & 26,503 & 233,723 & 80,490 & 72,239 & 1,290 & 26,503 & 233,723 & 80,490 & 72,239 \\
\hline $2004 / 05$ & 1,312 & 28,034 & 235,097 & 77,454 & 68,464 & 1,312 & 28,034 & 235,097 & 77,454 & 68,464 \\
\hline $2005 / 06$ & 1,352 & 30,271 & 238,975 & 80,155 & 78,543 & 1,352 & 30,271 & 238,975 & 80,155 & 78,543 \\
\hline $2006 / 07$ & 1,361 & 29,131 & 232,926 & 78,233 & 73,235 & 1,361 & 29,131 & 232,926 & 78,233 & 73,235 \\
\hline $2007 / 08$ & 1,369 & 30,158 & 239,652 & 88,221 & 74,230 & 1,369 & 30,158 & 239,652 & 88,221 & 74,230 \\
\hline $2008 / 09$ & 1,367 & 30,683 & 241,726 & 86,654 & 70,672 & 1,367 & 30,683 & 241,726 & 86,654 & 70,672 \\
\hline $2009 / 10$ & 1,361 & 31,018 & 247,441 & 88,069 & 77,258 & 1,361 & 31,018 & 247,441 & 88,069 & 77,258 \\
\hline $2010 / 11$ & 1,338 & 29,837 & 247,220 & 87,084 & 76,865 & 1,338 & 29,837 & 247,220 & 87,084 & 76,865 \\
\hline $2011 / 12$ & 1,320 & 27,672 & 247,717 & 86,825 & 78,341 & 1,320 & 27,672 & 247,717 & 86,825 & 78,341 \\
\hline $2012 / 13$ & 1,318 & 27,327 & 245,892 & 86,026 & 77,364 & 1,318 & 27,327 & 245,892 & 86,026 & 77,364 \\
\hline
\end{tabular}

Source: EL.STAT.

As regards the private upper secondary schools (Lyceums) in Greece, according to the table above from 2000 to 2013 the number of private upper secondary schools remains essentially unchanged (90 school units in 2000 and 93 in 2013), while the number of both teachers and students declines slightly. Regarding the students who successfully completed the last grade of Lyceum and therefore the majority of them took the entrance exams for access to higher education, in 2011 out of 76,865 graduates, 5,028 were from private high schools, in 2012 from a total of 78,341 graduates, from private upper secondary schools were 5.120 students while in 2013 out of a total of 77,364 students who graduated from Lyceum in Greece 5,074 were graduates of private school units.

Trying to interpret the educational choices of private high school graduates in Greece, we first observe that the probability ratio for participating in tertiary education for private school graduates is approximately equal to 1.0 during the whole decade (2001-2011), which indicates that the chances of participating in tertiary education are equal between graduates of public

${ }^{3}$ Including pupils enrolled in the 1st grade, as well as pupils who are re-enrolled. 
and private schools, thus both types of schools are represented equally in the Greek Tertiary education, while this trend has not changed significantly over time (Figure 2).

However, this doesn't seem to be the case for neither all sectors of Greek higher education, nor the educational institutions. There are significant differences between the three sectors of tertiary education. Private school graduates are overrepresented in Universities, while the probability ratio has been increasing since 2001 (Table 3). According to the latest available data (2011), graduates from private upper secondary schools are 1.46 times more likely to enter Universities than their peers from public schools. On the other hand, in Technological Sector (TEIs, Higher Vocational Education \& Higher Ecclesiastical Education) private schools graduates appear to be underrepresented with the proportion of private school graduates among freshmen to be $3.6 \%$ and $4.9 \%$ respectively in 2011 .

Figure 2. Private school graduates rates, and share of private school graduates among the tertiary education new entrants in Greece and probability ratio for participating in tertiary education $(2000 / 01-2011 / 12)$

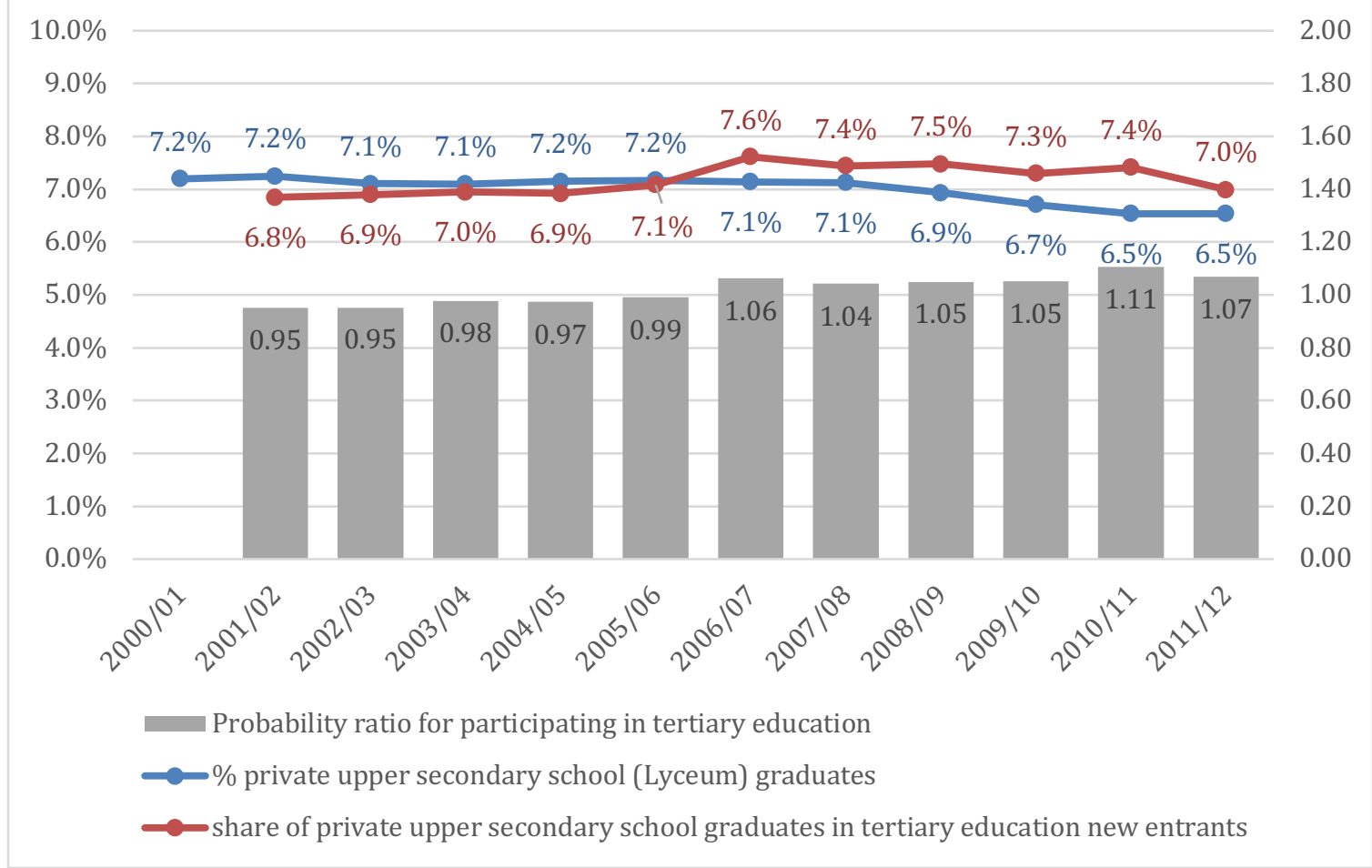

Source: a) EL.STAT.

b) KANEP/GSEE (2014) 
Table 3. Entrance in tertiary education of private upper secondary schools graduates (2001-2011)

\begin{tabular}{|c|c|c|c|c|c|c|c|c|c|c|c|c|}
\hline Indicators & $\begin{array}{c}\text { Type of } \\
\text { institution }\end{array}$ & 2001 & 2002 & 2003 & 2004 & 2005 & 2006 & 2007 & 2008 & 2009 & 2010 & 2011 \\
\hline \multirow{4}{*}{ 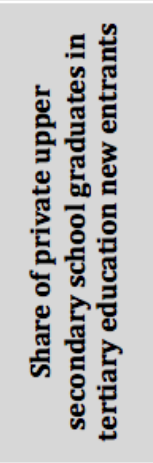 } & Universities & $8.9 \%$ & $9.1 \%$ & $9.4 \%$ & $9.4 \%$ & $9.7 \%$ & $10.0 \%$ & $9.6 \%$ & $9.9 \%$ & $9.8 \%$ & $10.3 \%$ & $9.6 \%$ \\
\hline & $\begin{array}{l}\text { TEI } \\
\text { (Technological } \\
\text { Educational } \\
\text { Institutes) \& } \\
\text { ASPAITE }\end{array}$ & $4.5 \%$ & $4.3 \%$ & $4.2 \%$ & $4.0 \%$ & $4.0 \%$ & $4.6 \%$ & $4.8 \%$ & $4.6 \%$ & $4.4 \%$ & $4.0 \%$ & $3.6 \%$ \\
\hline & $\begin{array}{l}\text { Higher Vocational } \\
\text { Education \& } \\
\text { Higher } \\
\text { Ecclesiastical } \\
\text { Education }\end{array}$ & $3.9 \%$ & $4.3 \%$ & $3.3 \%$ & $3.5 \%$ & $3.2 \%$ & $5.7 \%$ & $5.9 \%$ & $4.9 \%$ & $5.2 \%$ & $5.2 \%$ & $4.9 \%$ \\
\hline & $\begin{array}{l}\text { TOTAL Tertiary } \\
\text { education }\end{array}$ & $6.8 \%$ & $6.9 \%$ & $7.0 \%$ & $6.9 \%$ & $7.1 \%$ & $7.6 \%$ & $7.4 \%$ & $7.5 \%$ & $7.3 \%$ & $7.4 \%$ & $7.0 \%$ \\
\hline \multirow{4}{*}{ 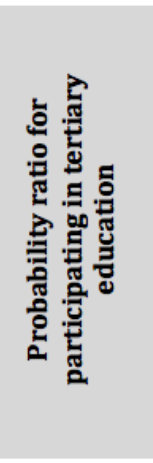 } & Universities & 1.24 & 1.25 & 1.32 & 1.32 & 1.36 & 1.40 & 1.34 & 1.39 & 1.42 & 1.53 & 1.46 \\
\hline & $\begin{array}{l}\text { TEI } \\
\text { (Technological } \\
\text { Educational } \\
\text { Institutes) \& } \\
\text { ASPAITE }\end{array}$ & 0.62 & 0.59 & 0.59 & 0.57 & 0.56 & 0.65 & 0.67 & 0.64 & 0.63 & 0.60 & 0.56 \\
\hline & $\begin{array}{l}\text { Higher Vocational } \\
\text { Education \& } \\
\text { Higher } \\
\text { Ecclesiastical } \\
\text { Education }\end{array}$ & 0.54 & 0.59 & 0.47 & 0.50 & 0.45 & 0.79 & 0.83 & 0.69 & 0.74 & 0.77 & 0.75 \\
\hline & $\begin{array}{l}\text { TOTAL Tertiary } \\
\text { education }\end{array}$ & 0.95 & 0.95 & 0.98 & 0.97 & 0.99 & 1.06 & 1.04 & 1.05 & 1.05 & 1.11 & 1.07 \\
\hline \multicolumn{2}{|c|}{$\begin{array}{l}\text { \% private upper secondary } \\
\text { school (Lyceum) graduates }\end{array}$} & $7.2 \%$ & $7.2 \%$ & $7.1 \%$ & $7.1 \%$ & $7.2 \%$ & $7.2 \%$ & $7.1 \%$ & $7.1 \%$ & $6.9 \%$ & $6.7 \%$ & $6.5 \%$ \\
\hline
\end{tabular}

Source: a) EL.STAT.

b) KANEP/GSEE (2014) 
Table 4. Share of private upper secondary school graduates in tertiary education new entrants Reference year: 2011

\begin{tabular}{|c|c|c|c|c|c|}
\hline & \multirow{2}{*}{ Educational institution } & \multicolumn{4}{|c|}{$\begin{array}{l}\text { Descriptive statistics } \\
\text { (values per department) }\end{array}$} \\
\hline & & Min & $\begin{array}{l}\text { Mean } \\
\text { value }\end{array}$ & Max & Range \\
\hline & Universities & $0,0 \%$ & $9,6 \%$ & $40,4 \%$ & $40,4 \%$ \\
\hline 1 & National and Kapodistrian University of Athens & $0,0 \%$ & $11,2 \%$ & $22,3 \%$ & $22,3 \%$ \\
\hline 2 & University of the Aegean & $0,0 \%$ & $7,9 \%$ & $17,2 \%$ & $17,2 \%$ \\
\hline 3 & University of Thessaly & $0,8 \%$ & $8,3 \%$ & $23,8 \%$ & $23,0 \%$ \\
\hline 4 & Aristotle University of Thessaloniki & $1,9 \%$ & $9,4 \%$ & $22,6 \%$ & $20,7 \%$ \\
\hline 5 & Democritus University of Thrace & $0,6 \%$ & $7,1 \%$ & $14,7 \%$ & $14,1 \%$ \\
\hline 6 & Ionian University & $3,8 \%$ & $6,8 \%$ & $10,4 \%$ & $6,6 \%$ \\
\hline 7 & University of Ioannina & $2,3 \%$ & $7,8 \%$ & $17,8 \%$ & $15,5 \%$ \\
\hline 8 & University of Crete & $1,5 \%$ & $7,0 \%$ & $15,6 \%$ & $14,2 \%$ \\
\hline 9 & University of Patras & $2,7 \%$ & $10,3 \%$ & $19,6 \%$ & $16,9 \%$ \\
\hline 10 & Athens University of Economics and Business & $10,8 \%$ & $15,3 \%$ & $21,3 \%$ & $10,6 \%$ \\
\hline 11 & Panteion University of Social and Political Sciences & $0,5 \%$ & $9,0 \%$ & $17,1 \%$ & $16,5 \%$ \\
\hline 12 & University of Piraeus & $0,0 \%$ & $9,0 \%$ & $16,1 \%$ & $16,1 \%$ \\
\hline 13 & University of Macedonia & $0,0 \%$ & $9,3 \%$ & $16,9 \%$ & $16,9 \%$ \\
\hline 14 & Agricultural University of Athens & $4,1 \%$ & $9,6 \%$ & $15,5 \%$ & $11,5 \%$ \\
\hline 15 & Athens University of Fine Arts & $18,9 \%$ & $23,8 \%$ & $28,6 \%$ & $9,6 \%$ \\
\hline 16 & Harokopio University & $3,6 \%$ & $8,9 \%$ & $13,7 \%$ & $10,1 \%$ \\
\hline 17 & University of Peloponnese & $2,7 \%$ & $7,0 \%$ & $14,9 \%$ & $12,2 \%$ \\
\hline 18 & University of Western Macedonia & $1,5 \%$ & $4,8 \%$ & $7,6 \%$ & $6,1 \%$ \\
\hline 19 & University of Central Greece & $8,0 \%$ & $8,3 \%$ & $8,6 \%$ & $0,6 \%$ \\
\hline 20 & University of Western Greece & $0,8 \%$ & $4,2 \%$ & $9,1 \%$ & $8,3 \%$ \\
\hline 21 & Technical University of Crete & $5,0 \%$ & $14,2 \%$ & $18,8 \%$ & $13,8 \%$ \\
\hline \multirow[t]{3}{*}{22} & National Technical University of Athens (NTUA) & $10,4 \%$ & $22,5 \%$ & $40,4 \%$ & $30,0 \%$ \\
\hline & TEI (Technological Educational Institutes) & $0,0 \%$ & $3,6 \%$ & $15,1 \%$ & $15,1 \%$ \\
\hline & $\begin{array}{l}\text { Higher Vocational Education \& Higher Ecclesiastical } \\
\text { Education }\end{array}$ & $0,0 \%$ & $4,9 \%$ & $27,3 \%$ & $27,3 \%$ \\
\hline- & GNT Drama School & $13,5 \%$ & $13,5 \%$ & $13,5 \%$ & $0,0 \%$ \\
\hline \multirow[t]{2}{*}{-} & $\begin{array}{l}\text { Drama School of the National Theatre of Northern } \\
\text { Greece }\end{array}$ & $27,3 \%$ & $27,3 \%$ & $27,3 \%$ & $0,0 \%$ \\
\hline & TOTAL in tertiary education & $0,0 \%$ & $7,0 \%$ & $40,4 \%$ & $40,4 \%$ \\
\hline
\end{tabular}

\section{Source: KANEP/GSEE (2014)}

However, in addition to the general statistics demonstrating the over-representation of private upper secondary school graduates throughout the university departments of the country, it is particularly interesting to map the educational choices of these students. Thus, while the proportion of private Lyceum graduates is low in the Technological Educational Institutions (TEIs) of the country (3.6\%) and a number of universities of the periphery such as the University of Western Greece (4.2\%), the University of Western Macedonia (4.8\%) \%), the Ionian University (6.8\%) and the Universities of the Peloponnese and Crete (7\%), respectively, the percentage of private Lyceum graduates appear to be particularly high at high-demand and prestigious universities such as the National Technical University of Athens (NTUA) (22.3\%) , Athens University of Economics and Business (15.3\%), Technical University of Crete (14.2\%) and National and Kapodistrian University of Athens (11.2\%). Also worth mentioning is the over-representation of private upper secondary school graduates in art and culture schools, as the $23.8 \%$ of freshmen at the Athens University of Fine Arts, the $27.3 \%$ of the Drama School of the National Theater of Northern Greece and the $13.5 \%$ of new entrants of the Drama School of 
the National Theater of Greece are graduates of private educational institutions (Table 4). It is noteworthy that shares of private school graduates vary significantly even among departments. For example, while in National Technical University of Athens (NTUA) the average proportion of private school graduates is $22.5 \%$, this figure ranges widely from $10.4 \%$ to $40.4 \%$ among its departments. In other words, within one of its departments 4 out of 10 freshmen have been graduated from a private school, which is tremendously higher than their overall proportion of $7.0 \%$ in tertiary education.

Table 5. Likelihood of participating in tertiary education for graduates from private upper secondary schools per field of study

\begin{tabular}{|c|c|c|c|c|c|}
\hline & \multirow[t]{2}{*}{ Field of study* } & \multicolumn{4}{|c|}{$\begin{array}{l}\text { Share of private upper secondary } \\
\text { school graduates in tertiary } \\
\text { education new entrants }\end{array}$} \\
\hline & & Min & Mean & Max & Range \\
\hline & Total in tertiary education & $0,0 \%$ & $7,0 \%$ & $40,4 \%$ & $40,4 \%$ \\
\hline 1400 & Teacher training and education science & $0,0 \%$ & $4,3 \%$ & $15,4 \%$ & $15,4 \%$ \\
\hline 2100 & Arts & $1,8 \%$ & $9,4 \%$ & $28,6 \%$ & $26,8 \%$ \\
\hline 2200 & Humanities & $0,0 \%$ & $5,6 \%$ & $16,1 \%$ & $16,1 \%$ \\
\hline 3100 & Social and behavioural science & $0,0 \%$ & $8,3 \%$ & $17,9 \%$ & $17,9 \%$ \\
\hline 3200 & Journalism and information & $0,0 \%$ & $5,6 \%$ & $17,1 \%$ & $17,1 \%$ \\
\hline 3400 & Business and administration & $0,0 \%$ & $5,2 \%$ & $18,8 \%$ & $18,8 \%$ \\
\hline 3800 & Law & $10,5 \%$ & $14,9 \%$ & $20,5 \%$ & $10,1 \%$ \\
\hline 4200 & Life sciences & $0,0 \%$ & $11,6 \%$ & $19,3 \%$ & $19,3 \%$ \\
\hline 4400 & Physical sciences & $6,3 \%$ & $11,5 \%$ & $16,5 \%$ & $10,3 \%$ \\
\hline 4600 & Mathematics and statistics & $3,1 \%$ & $8,8 \%$ & $20,8 \%$ & $17,7 \%$ \\
\hline 4800 & Computing & $1,0 \%$ & $5,7 \%$ & $21,3 \%$ & $20,3 \%$ \\
\hline 5200 & Engineering and engineering trades & $1,0 \%$ & $8,6 \%$ & $40,4 \%$ & $39,4 \%$ \\
\hline 5400 & Manufacturing and processing & $0,9 \%$ & $4,7 \%$ & $12,6 \%$ & $11,7 \%$ \\
\hline 5800 & Architecture and building & $0,0 \%$ & $9,1 \%$ & $22,9 \%$ & $22,9 \%$ \\
\hline 6200 & Agriculture, forestry and fishery & $0,0 \%$ & $6,9 \%$ & $15,5 \%$ & $15,5 \%$ \\
\hline 6400 & Veterinary & $5,6 \%$ & $8,8 \%$ & $12,0 \%$ & $6,4 \%$ \\
\hline 7200 & Health & $0,0 \%$ & $6,9 \%$ & $23,8 \%$ & $23,8 \%$ \\
\hline 7600 & Social services & $2,0 \%$ & $2,5 \%$ & $2,9 \%$ & $0,9 \%$ \\
\hline 8100 & Personal services & $0,0 \%$ & $3,6 \%$ & $5,6 \%$ & $5,6 \%$ \\
\hline 8400 & Transport services & $0,0 \%$ & $3,3 \%$ & $7,1 \%$ & $7,1 \%$ \\
\hline 8500 & Environmental protection & $0,0 \%$ & $1,7 \%$ & $5,0 \%$ & $5,0 \%$ \\
\hline
\end{tabular}

*according to ISCED 1997 classification (UNESCO, 1997)

8600: Security services are excluded from the analysis

Source: KANEP/GSEE (2014)

Regarding the fields of study chosen by private high school graduates in Greece, we note that the representation of these high school graduates is significantly increased in high - profile and prestigious scientific subjects. Indicatively, with the average of new entrants coming from private schools amounting to $7 \%$ of all Higher Education Institutions, the proportion in law schools is $14.9 \%$, in life sciences $11.6 \%$, in the physical sciences $11.5 \%$ and the Art Schools $9.4 \%$. On the other hand, private school graduates appear to be underrepresented in schools related to Environmental protection (1.7\%), Social services (2.5\%), Transport services (3.3\%), and Personal services (3.6\%). 


\section{CONCLUSION}

Concerning the above analysis, we are able to finalize our approach by providing particular conclusions. It is certain that in modern Greece the demand of tertiary education remains as one of the most significant social request. Undoubtedly educational apparatuses are still functioning as strong instruments of occupational and social upward mobility into the sovereign social stratification. However, the widen of educational opportunities at institutional level didn't reduce drastically the diachronic educational and social inequalities which are being reflected into the educational mechanisms of the entry examinations. Specifically, this means that private schools still play a distinguished role to the state examination results to prestigious Universities emerging their comparative advantage through a deliriously competitive system of educational/social selection. According to the above empirical data we observe the statistically high representation of graduates from private schools in high - profile, prestigious and capital Universities. We can also spot a high over-representation to prestigious scientific fields as well as to cultural studies emerging the high demand for educational pathways which are closer to their "cultural habitus". It is certain that in Greece the period of crisis increased the intensity of economic and social inequalities by reflecting the increased differentiation to the relationship between opportunities and results into the operation of educational apparatuses.

\section{References}

Ball, S. and Vincent, C. (2011) New Class Relations in Education: the Strategies of the 'Fearful' Middle Classes. In Demaine, J. (ed.) Sociology of education today. London: Palgrave.

Giroux, H. (1983). Theories of reproduction and resistance in the new sociology of education: A critical analysis. Harvard educational review, 53(3), 257-293.

Gouvias, D. (1998). Selection in Europe--the Case of Greece. education policy analysis archives, 6, 4.

Gouvias, D. (1998). The National Examination's System of Greece and its function as a mechanism of social selection. (Latest Access in http://www.leeds.ac.uk/educol/documents /000000890.htm 2/11/2019)

KANEP/GSEE (2014). Annual report on education - Part B: The national reference context of tertiary education (Latest Access in https://www.kanep-gsee.gr/sitefiles/files/etekth2014.pdf 5/11/2019)

Kassotakis, M., \& Verdis, A. (2013). Shadow education in Greece: Characteristics, consequences and eradication efforts. In Private Tutoring Across the Mediterranean (pp. 93-113). Brill Sense.

Sianou-Kyrgiou, E. (2008). Social class and access to higher education in Greece: Supportive preparation lessons and success in national exams. International Studies in Sociology of Education, 18(3-4), 173-183.

Sianou-Kyrgiou, E. (2010). Stratification in higher education, choice and social inequalities in Greece. Higher Education Quarterly, 64(1), 22-40.

Therianos, K. \& Fotopoulos, N. (2011). School choice and social class strategies. In M. Antonopoulos \& S. Koniordos (Eds.): Greek Society 1975 - 2010: Transformations, Rearrangements, Challenges [Proceedings of the 3rd Regular Conference of the Hellenic Sociological Society, Athens November 3 - 5, 2011. Available at: http:

//www.hellenicsociology .gr / sites / default / files / eke_praktika_2011.pdf]. (In Greek)

Zambeta, E., \& with the assistance of Asimina Kolofousi. (2014). Education and Social Solidarity in times of Crisis: the case of voluntary shadow education in Greece. Education Inquiry, 5(1), 24058.

Whitty G., Power, S. and Halpin, D. (1998) Devolution and Choice in Education: The school, the state and the market. Buckingham: Open University Press. 